\title{
Childhood Maltreatment and Psychological Adjustment: A Systematic Review
}

\section{Maus-Tratos na Infância e Ajustamento Psicológico: Uma Revisão Sistemática}

\author{
Janaína Thais Barbosa Pacheco ${ }^{a}$, Tatiana Quarti Irigaray*, ${ }^{*}$, Blanca Werlang (in memoriam), \\ Maria Lucia Tiellet Nunes ${ }^{b} \&$ Irani Iracema de Lima Argimon ${ }^{b}$ \\ ${ }^{a}$ Universidade Federal de Ciências da Saúde de Porto Alegre, Porto Alegre, RS, Brasil \\ \& ${ }^{b}$ Pontificia Universidade Católica do Rio Grande do Sul, Porto Alegre, RS, Brasil
}

\begin{abstract}
This study aimed to investigate the effects of exposure to child maltreatment on self-esteem, social competence, peer relationships and school performance through a systematic literature review. For this purpose, a search of articles indexed in Medline, PsycINFO, Embase and Amed databases between 1984 and 2012 was done. In this review, 19 empirical articles in English were analyzed based on inclusion/exclusion criteria. These studies highlight that, overall, both adults and children/teenagers who were exposed to maltreatment during childhood showed impairments on self-esteem, social competence, peer relationships, and school performance. The analysis of the articles has also allowed the identification of the instruments used to assess the variables of interest and the description of the profile of those who participated of the studies included in this review.

Keywords: Maltreatment, self-esteem, social competence, peers, school performance.

Resumo

Este estudo teve por objetivo investigar os efeitos da exposição a maus-tratos sobre a autoestima, a competência social, a relação com pares e o desempenho acadêmico por meio de revisão sistemática da literatura. Para isso foi realizada uma busca de artigos indexados nos bancos de dados Medline, PsycINFO, Embase e Amed, publicados entre 1984 e 2012. Nesta revisão, 19 artigos empíricos e no idioma inglês foram analisados a partir de critérios de inclusão/exclusão. Os estudos destacam que, de maneira geral, adultos ou crianças/adolescentes que sofreram maus tratos na infância apresentaram prejuízos na autoestima, na competência social, na relação com pares e no desempenho acadêmico. A análise dos artigos permitiu, ainda, a identificação dos instrumentos utilizados para a avaliação das variáveis de interesse e a descrição do perfil dos participantes dos estudos incluídos nessa revisão. Palavras-chave: Maus-tratos, autoestima, competência social, pares, desempenho acadêmico.
\end{abstract}

The exposure to conditions of abuse and neglect during childhood has been associated with an increased risk of psychological, social, and behavioral impairment (Kim \& Cicchetti, 2010). Studies suggest that degree of impairment depends on the type of abuse involved as well as its severity (Kim \& Cicchetti, 2010; Pears, Kim, \& Fisher, 2008). There is also evidence that abused children are generally exposed to more than one type of maltreatment (Pears et al., 2008). Therefore, to better understand the impact of maltreatment on child development, specific instruments and analyses must be developed to assess the

\footnotetext{
" Mailing address: Pontifícia Universidade Católica do Rio Grande do Sul, Av. Ipiranga, 6681, Partenon, Porto Alegre, RS, Brasil 90619-900. E-mail: janainapacheco@ uol.com.br, tatiana.irigaray@superig.com.br and argimoni@pucrs.br

Support: Coordenação de Aperfeiçoamento de Pessoal de Nível Superior (CAPES) / Conselho Nacional de Desenvolvimento Científico e Tecnológico (CNPq) and Fundação de Amparo à Pesquisa do Estado do Rio Grande do Sul (FAPERGS).
}

type and severity of the abuse involved in situations of child maltreatment.

Individuals exposed to maltreatment present significant impairment in important developmental aspects such as emotion regulation, the development of attachment, autonomy, peer relationships, adaptation to school, and self-esteem (Cicchetti \& Rogosch, 2002; Cicchetti \& Valentino, 2006; Kim \& Cicchetti, 2010; Masten \& Coatsworth, 1998). Furthermore, because they are more likely to suffer more than one type of impairment during early development, victims of child maltreatment are also more susceptible to behavioral problems and psychological disorders both during childhood and the remainder of their development (Kim \& Cicchetti, 2010; Rogosch, Oshri, \& Cicchetti, 2010). Proctor, Skriner, Roesch and Litrownik (2010) note that little is known about the predictors of behavioral adjustment in individuals exposed to maltreatment. A study these authors showed that positive social adjustment is associated with early cognitive abilities, social competence, caretaker stability, and low frequency 
of physical abuse in middle childhood and adolescence (Proctor et al., 2010).

The impact of exposure to maltreatment on psychological adjustment has been investigated through the variables that make up this construct, such as academic performance, self esteem and social competence. Relationships among exposure to maltreatment, academic failure, and development of psychopathology have been reported in a number of studies (Buckle, Lancaster, Powell, \& Higgins, 2005; Cicchetti, Toth, \& Maughan, 2000; Shonk \& Cicchetti, 2001). Children who are victims of maltreatment tend to have lower grades in school, exhibit impairment in standardized tests, and display poorer academic performance as compared to children who were not maltreated (Buckle et al., 2005).

Even in school, disadvantages in relation to their peers are found (Chapple, Tyler, \& Bersani, 2005; Cicchetti et al., 2000; Kim \& Cicchetti, 2010). Children who experience abuse and neglect tend to react with greater aggressiveness toward peers or to remain socially isolated (Bolger, Patterson, \& Kupersmidt, 1998; Dodge, Pettit, \& Bates, 1994).

Research regarding psychological adjustment has also looked into the impact of childhood maltreatment upon social competence and self-esteem (Kim \& Cicchetti, 2004; Shen, 2009; Van Bruggen, Runtz, \& Kadlec, 2006). Low self-esteem is a common long-term effect of exposure to physical abuse (Shen, 2009) and sexual abuse (Kendall-Tackett, Williams, \& Finkelhor, 1993). A study by Levendosky, Okun and Parker (1995) found that depression was the strongest predictor of social competence scores. Children with depression associated with abuse had poorer social competence as assessed by parents and teachers, leading to an even greater risk of problems in future relationships.

As discussed, the effects of exposure to child maltreatment on self-esteem, social competence, relationships with peers, and school performance have been widely investigated by international studies. However, in Brazil, studies about the relationship between these variables are scarce. National studies have focused on aspects such as the prevalence and consequences of abuse, especially sexual abuse, in certain situations and their related factors (Amazarray \& Koller, 1998; Drezett et al., 2001), the risk of developing mental illness in individuals exposed to maltreatment (Bordin et al., 2009; Borges \& Dell'Aglio, 2008; Vitolo, Fleitlich-Bilyk, Goodman, \& Bordin, 2005) and the development of group interventions for victims of sexual abuse (Habigzang et al., 2009). Furthermore, most of these published studies did not compare groups with the presence and absence of childhood maltreatment.

Considering the evidence regarding the impact of childhood maltreatment upon development, the present study aimed to answer the following research question: how does exposure to childhood maltreatment affect psychological adjustment? To investigate this issue, the present article carried out a critical, systematic review of studies investigating the effects of exposure to childhood maltreatment upon self-esteem, social competence, relationships with peers, and academic performance.

\section{Method}

A systematic review was carried out in search of studies investigating the effects of exposure to childhood maltreatment upon psychological adjustment. The dependent variable childhood maltreatment was defined according to Bernstein and colleagues (1994; Bernstein et al., 2003), and included traumatic experiences of physical, emotional, and sexual abuse, as well as emotional or physical neglect. A systematic review was conducted based on Mulrow and Oxman (1997).

The Medline, PsycINFO, Embase and Amed databases were searched using the following terms: "maltreatment" and "child" and "self-esteem" or "social competence" or "academic achievement" (or scholastic achievement) or "peers" and "child". The articles obtained were then filtered based on the following characteristics: (a) presence of an abstract; (b) text in the English language; (c) empirical study; (d) publication in a peer-reviewed journal; (e) research on human subjects; (f) presence of a reference list. Qualitative and duplicate articles were excluded. Results were not filtered by publication year.

The initial search returned 349 abstracts published between 1984 and 2012. Two independent judges read each abstract and selected articles according to the following inclusion criteria: (a) empirical investigations of maltreatment and self-esteem, social competence, academic performance or peer relationships; (b) crosssectional, case-control, randomized clinical trial or cohort study design; (c) at least one control group composed of individuals with no history of maltreatment. All inclusion and exclusion criteria aimed ensured the selection of studies with a higher level of evidence. In case of disagreement between the two judges, the criteria have been resumed and discussed by both with a third judge in order to seek a consensus.

After application of inclusion criteria, the initial sample was reduced to 38 articles. Then, after full text reading, 19 articles were excluded as their objectives were not in line with those investigated by the present study. After exclusions, 19 articles were included in the present systematic review. The Figure 1 shows the flowchart of the systematic review performed in this study.

\section{Results and Discussion}

The results will be presented and discussed in two distinct sections. The first section will describe the methods employed in the studies as well characteristics of samples and assessment instruments used in the investigations. The second section, the main findings regarding the effects of 
Pacheco, J. T. B., Irigaray, T. Q., Werlang, B. (in memoriam), Nunes, M. L. T. \& Argimon, I. I. L. (2014). Childhood Maltreatment and Psychological Adjustment: A Systematic Review.

MEDLINE, PsycINFO, Embase, and Amed (Ovid) search using the terms "maltreatment" and "child" and "self-esteem" or "social competence" or "academic achievement" (or scholastic achievement) or "peers" e "child".

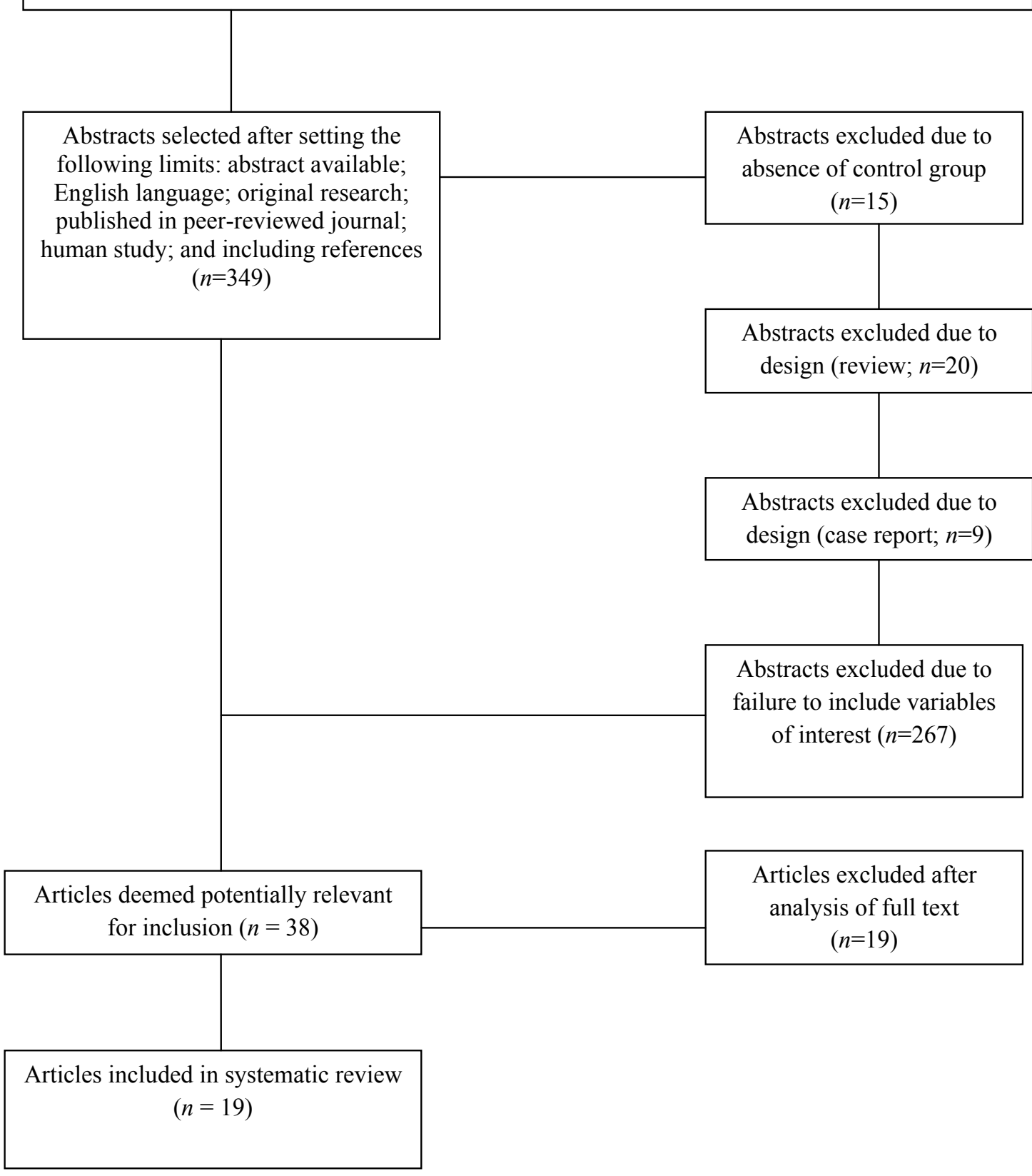

Figure 1. Article selection flowchart.

childhood maltreatment on self-esteem, social competence, academic performance and peer relationships will be discussed.

Methodology of Studies and Instruments Used to Assess Maltreatment, Self-Esteem, Social Competence, Academic Performance and Peer Relationships

All selected studies involved an experimental group (EG) including individuals with a history of abuse, and a control group (CG) whose members had no such history. Studies were published between 1989 and 2012. Out of the 19 studies analyzed, 12 were cross-sectional, six were cohort studies and one involved a case-control design.

Table 1 presents the analyzed studies and the number of participants per group in each case. A total of 8014 participants were analyzed in the 19 studies. Fifteen studies investigated 4947 children or adolescents aged between 0 and 18 years, $58.4 \%$ of whom had been exposed to maltreatment. The remaining four studies analyzed 3067 adults aged between 21 and 61 years, $38.5 \%$ of whom were part of the EG. 
Psicologia: Reflexão e Crítica, 27(4), 815-824.

Table 1

Description of the Selected Studies, Including Sample Size, Variables Analyzed and Instruments Used

\begin{tabular}{|c|c|c|c|}
\hline Author (year) & Sample $(N)$ & Variables analyzed & Instruments used \\
\hline \multicolumn{4}{|c|}{ Studies with adults } \\
\hline $\begin{array}{l}\text { Arata, Langhinrichsen-Rohling, } \\
\text { Bowers, \& O'Farrill-Swails } \\
(2005)\end{array}$ & 384 & $\begin{array}{l}\text { Maltreatment } \\
\text { Self-esteem }\end{array}$ & $\begin{array}{l}\text { Childhood Trauma Questionnaire (CTQ; } \\
\text { Bernstein et al., 1994) } \\
\text { Self-Esteem Scale (Rosenberg, 1965) }\end{array}$ \\
\hline Van Bruggen et al. (2006) & 402 & $\begin{array}{l}\text { Maltreatment } \\
\text { Self-esteem }\end{array}$ & $\begin{array}{l}\text { Childhood maltreatment interview schedule short } \\
\text { form (CMIS-F) } \\
\text { Sexual Self-Esteem Inventory for Women } \\
\text { (SSEI-W) }\end{array}$ \\
\hline Shen (2009) & 1924 & $\begin{array}{l}\text { Maltreatment } \\
\text { Self-esteem }\end{array}$ & $\begin{array}{l}\text { Conflict Tactics Scales, Physical Assault SubScale } \\
\text { Self-Esteem Scale (Rosenberg, 1965) - Chinese } \\
\text { Version }\end{array}$ \\
\hline $\begin{array}{l}\text { Herrenkohl, Klika, Herrenkohl, } \\
\text { Russo, \& Dee (2012) }\end{array}$ & 357 & $\begin{array}{l}\text { Maltreatment } \\
\text { Self-esteem }\end{array}$ & $\begin{array}{l}\text { Protection programs or official registries } \\
\text { Self-Esteem Scale (Rosenberg, 1965) }\end{array}$ \\
\hline \multicolumn{4}{|c|}{ Studies with children } \\
\hline $\begin{array}{l}\text { Vondra, Barnett, \& Cicchetti } \\
\text { (1989) }\end{array}$ & 104 & $\begin{array}{l}\text { Maltreatment } \\
\text { Social competence }\end{array}$ & $\begin{array}{l}\text { Not described in the article } \\
\text { Harter's Perceived Competence }\end{array}$ \\
\hline Kaufman \& Cicchetti (1989) & 137 & $\begin{array}{l}\text { Maltreatment } \\
\text { Self-esteem }\end{array}$ & $\begin{array}{l}\text { Protection programs or official registries } \\
\text { California Child Q-sort }\end{array}$ \\
\hline $\begin{array}{l}\text { Hibbard, Spence, Tzeng, } \\
\text { Zollinger, \& Orr (1992) }\end{array}$ & 82 & $\begin{array}{l}\text { Maltreatment } \\
\text { Self-esteem }\end{array}$ & $\begin{array}{l}\text { Protection programs or official registries } \\
\text { Janis-Field Feelings of Inadequacy Scale }\end{array}$ \\
\hline $\begin{array}{l}\text { Eckenrode, Laird, \& Doris } \\
\text { (1993) }\end{array}$ & 840 & $\begin{array}{l}\text { Maltreatment } \\
\text { Academic } \\
\text { performance }\end{array}$ & $\begin{array}{l}\text { Protection programs or official registries } \\
\text { School reports. Standardized Iowa Test of Basic } \\
\text { Skills scores. Final grades in reading/English and } \\
\text { mathematics. Number of failed grades }\end{array}$ \\
\hline Bolger et al. (1998) & 214 & $\begin{array}{l}\text { Maltreatment } \\
\text { Self-esteem } \\
\text { Peer relationships }\end{array}$ & $\begin{array}{l}\text { Protection programs or official registries } \\
\text { Self-Perception Profile (Harter, 1985) } \\
\text { Peer nomination task }\end{array}$ \\
\hline Kinard (1999a) & 334 & $\begin{array}{l}\text { Maltreatment } \\
\text { Social competence }\end{array}$ & $\begin{array}{l}\text { Not described in the article } \\
\text { Harter self-perception profile for children }\end{array}$ \\
\hline Kinard (1999b) & 334 & $\begin{array}{l}\text { Maltreatment } \\
\text { Academic } \\
\text { performance }\end{array}$ & $\begin{array}{l}\text { Protection programs or official registries } \\
\text { Wide Range Achievement Test (WRAT) }\end{array}$ \\
\hline Lynch \& Cicchetti (1998) & 322 & $\begin{array}{l}\text { Maltreatment } \\
\text { Self-esteem }\end{array}$ & $\begin{array}{l}\text { Protection programs or official registries } \\
\text { Self-Esteem Inventory (SEI; Coopersmith, 1981) }\end{array}$ \\
\hline Sullivan \& Knutson (2000) & 562 & $\begin{array}{l}\text { Maltreatment } \\
\text { Academic } \\
\text { performance }\end{array}$ & $\begin{array}{l}\text { Protection programs or official registries } \\
\text { California Achievement Test. School attendance }\end{array}$ \\
\hline Kinard (2001) & 374 & $\begin{array}{l}\text { Maltreatment } \\
\text { Academic } \\
\text { performance }\end{array}$ & $\begin{array}{l}\text { Protection programs or official registries } \\
\text { Harter Self-Perception Porfile for children. Wide } \\
\text { Range Achievement (WRAT) }\end{array}$ \\
\hline
\end{tabular}


Pacheco, J. T. B., Irigaray, T. Q., Werlang, B. (in memoriam), Nunes, M. L. T. \& Argimon, I. I. L. (2014). Childhood Maltreatment and Psychological Adjustment: A Systematic Review.

\begin{tabular}{|c|c|c|c|}
\hline Kim \& Cicchetti, (2004) & 345 & $\begin{array}{l}\text { Maltreatment } \\
\text { Self-esteem } \\
\text { Social competence }\end{array}$ & $\begin{array}{l}\text { Protection programs or official registries } \\
\text { Self-Esteem Inventory (SEI; Coopersmith, 1981) } \\
\text { Pupil Evaluation Inventory (PEI). }\end{array}$ \\
\hline $\begin{array}{l}\text { De Bellis, Hooper, Spratt, \& } \\
\text { Woolley (2009) }\end{array}$ & 106 & $\begin{array}{l}\text { Maltreatment } \\
\text { Academic } \\
\text { performance }\end{array}$ & $\begin{array}{l}\text { Protection programs or official registries } \\
\text { Woodcock-Johnson Tests of Academic } \\
\text { Achievement }\end{array}$ \\
\hline Kim \& Cicchetti (2010) & 421 & $\begin{array}{l}\text { Maltreatment } \\
\text { Peer relationships }\end{array}$ & $\begin{array}{l}\text { Protection programs or official registries } \\
\text { Peer nomination task }\end{array}$ \\
\hline $\begin{array}{l}\text { Soler, Paretilla, Kirchner, \& } \\
\text { Forns (2012) }\end{array}$ & 722 & $\begin{array}{l}\text { Maltreatment } \\
\text { Self-esteem }\end{array}$ & $\begin{array}{l}\text { Juvenile Victimization Questionnaire } \\
\text { Self-Esteem Scale (Rosenberg, 1965) }\end{array}$ \\
\hline Leeson \& Nixon (2011) & 50 & $\begin{array}{l}\text { Maltreatment } \\
\text { Self-esteem }\end{array}$ & $\begin{array}{l}\text { Childhood Trauma Questionnaire (CTQ; Bernstein } \\
\text { et al., 1994) } \\
\text { Self-Esteem Inventory (SEI; Coopersmith, 1981) }\end{array}$ \\
\hline
\end{tabular}

The mean age of EG participants was 11.5 years, vs. 11 year for CG participants. The studies by Arata et al. (2005), Herrenkohl et al. (2012), Kaufman and Cicchetti (1989), Kinard (2001), Leeson and Nixon (2011), Shen (2009), Soler et al. (2012) and Sullivan and Knutson (2000) did not report the mean age of participants for individual groups, describing only overall mean age for combined sample.

The studies by Arata et al. (2005), Kinard (2001), Soler et al. (2012) and Vondra et al. (1989), described the participants' level of education. In the first study, children had between three and eight years of schooling; in the second, participants had between three and six, while in the third, participants had between 9 and 12 years of formal education. Arata et al. (2005) did not provide information on the number of years of education, but did specify that the investigation was conducted with university students. The remaining studies did not present information related to level of education.

Most studies classified participants into two groups, considering the presence or absence of exposure to maltreatment. Ten studies classified individuals in the EG according to the type of maltreatment suffered (Arata et al., 2005; Bolger et al., 1998; Kim \& Cicchetti, 2004; 2010; Kinard, 1999a, 1999b; Lynch \& Cicchetti, 1998; Shen, 2009; Sullivan \& Knutson, 2000; Vondra et al., 1989). The categories investigated were sexual abuse (Eckenrode et al., 1993; Hibbard et al., 1992; Kinard, 2001; Leeson \& Nixon, 2011; Van Bruggen et al., 2006); physical abuse (Eckenrode et al., 1993; Herrenkohl et al., 2012; Hibbard et al., 1992; Kaufman \& Cicchetti, 1989; Kinard, 2001; Leeson \& Nixon, 2011; Soler et al., 2012; Van Bruggen et al., 2006); neglect (Eckenrode et al., 1993; Herrenkohl et al., 2012; Hibbard et al., 1992; Kaufman \& Cicchetti, 1989; Kinard, 2001; Leeson \& Nixon, 2011; Soler et al., 2012), and emotional abuse (Hibbard et al., 1992; Kaufman \& Cicchetti, 1989; Leeson \& Nixon, 2011; Soler et al., 2012; Van Bruggen et al., 2006). De Bellis et al. (2009) focused on victims of neglect.
As shown in Table 1, the selected studies assessed childhood maltreatment from various perspectives. Thirteen studies selected participants exposed to childhood maltreatment from protection programs or official registries, without using any specific assessment instrument (Bolger et al., 1998; De Bellis et al., 2009; Eckenrode et al., 1993; Herrenkohl et al., 2012; Hibbard et al., 1992; Kim \& Cicchetti, 2004, 2010; Kinard, 1999a, 1999b, 2001; Lynch \& Cicchetti, 1998; Shonk \& Cicchetti, 2001; Sullivan \& Knutson, 2000). Five studies used differents instruments to assess distinct types of maltreatments.

Self-esteem was assessed by 11 of the studies analyzed (Arata et al., 2005; Bolger et al., 1998; Herrenkohl et al., 2012; Hibbard et al., 1992; Kaufman \& Cicchetti, 1989; Kim \& Cicchetti, 2004; Leeson \& Nixon, 2011; Lynch \& Cicchetti, 1998; Shen, 2009; Soler et al., 2012; Van Bruggen et al., 2006). The instrument most commonly used to assess self-esteem was Rosenberg Self-Esteem Scale (Arata et al., 2005; Herronkohl et al., 2012; Shen, 2009; Soler et al., 2012).

Social competence was investigated by three studies (Kim \& Cicchetti, 2004; Kinard, 1999a; Vondra et al., 1989) using different assessment instruments. Kinard (1999a) used the 'social acceptance' subscale from the Harter Self-Perception Profile for Children to assess social competence. Harter's Perceived Competence Scale, used by Vondra et al., (1989), consists of a self-report instrument to assess cognitive and physical competence, as well as peer and maternal acceptance. Kim and Cicchetti (2004) assessed social competence through the Pupil Evaluation Inventory (PEI). The authors used the likeability subscale, which investigates prosocial behaviors.

Relationships with peers were the focus of two of the articles examined (Bolger et al., 1998; Kim \& Cicchetti, 2010), both of which assessed the variable through peer nomination tasks involving the appointment of colleagues they liked and they don't liked. Finally, academic performance was investigated by five studies 
(De Bellis et al., 2009; Eckenrode et al., 1993; Kinard, 1999b, 2001; Sullivan \& Knutson, 2000). Eckenrode et al. (1993) assessed academic performance from report cards as well as the following measures: (a) standardized scores in the Iowa Test of Basic Skills; (b) final grades in reading/English and mathematics; and (c) number of grade repetitions. Kinard (2001) explored this variable using the Harter Self-Perception Profile for Children and the Wide Range Achievement (WRAT). Some of the studies also used the Woodcock-Johnson Tests of Academic Achievement (De Bellis et al., 2009) and the California Achievement Test (Sullivan \& Knutson, 2000) to assess school performance.

According to the above, the selected studies used different ways to recruit participants. The majority of studies recruited participants in protection programs without using any specific instrument to assess maltreatment. This approach indicates that the identification of individuals in the EG groups depend on the reliability of the records of the programs. The most widely studied form of psychological adjustment was self-esteem, followed by academic performance, social competence and relationship with peers. The investigation of self-esteem indicated the existence of greater consistency between studies regarding the instruments used to measure this variable, primarily self report scales. The development of other studies that investigate other variables related to psychological adjustment seems necessary, including to enable the construction of appropriate instruments. These conceptual and methodological differences could create inconsistencies regarding the impact of maltreatment on psychological adjustment.

\section{Effect of the Exposure to Maltreatment on Self-Esteem, Social Competence, Academic Performance and Peer Relationships}

Analysis of the articles in this systematic review suggests that exposure to childhood maltreatment is associated with impairment in self-esteem (Arata et al., 2005; Bolger et al., 1998; Herrenkohl et al., 2012; Hibbard et al., 1992; Kim \& Cicchetti, 2004; Leeson \& Nixon, 2011; Lynch \& Cicchetti, 1998; Shen, 2009; Soler et al., 2012, Van Bruggen et al., 2006), social competence, relationships with peers, and academic performance (De Bellis et al., 2009; Eckenrode et al., 1993; Kaufman \& Cicchetti, 1989; Kim \& Cicchetti, 2010; Kinard, 1999b, 2001; Sullivan \& Knutson, 2000).

A wide range of results was obtained by studies looking into self-esteem in adolescents and children. Comparatives analyses between CG and EG indicated no statistically significant differences in some studies (Hibbard et al., 1992; Kim \& Cicchetti, 2004; Lynch \& Cicchetti, 1998), but the association analyzes were consistent in showing the relationship between the self-esteem and other variables related to psychological adjustment, such as depression, externalizing (Leeson \& Nixon, 2011) and relationship with peers (Bolger et al., 1998).
Comparative studies that indicated statistically significant differences have specific methodological characteristics, such as the division of EG in individuals exposed to only one type of maltreatment and exposed to more than one type of maltreatment (poly-victims) (Soler et al., 2012) or research in a clinical sample (Leeson \& Nixon, 2011). Soler et al. (2012) compared groups of adolescents aged 14 to 18 years, using the Rosenberg Self-Esteem Scale. The participants were divided into three groups: control, victims (exposed to one type of maltreatment) and polyvictims. The group of adolescents exposed to more than one type of maltreatment showed worse performance in self-liking, compared to the control group and the group exposed to only one type of maltreatment. Self-competence did not vary significantly according to the degree of participant victimization. This suggests that experiencing multiple types of abuse influences the perception of personal self-worth in adolescents, but not their sense of competence (Soler et al., 2012).

Leeson and Nixon (2011) conducted an investigation on a clinical sample of 24 children who had been exposed to maltreatment. The CG was composed of 26 children drawn from various schools in the area. The study found significant differences in self-esteem between groups. EG participants had lower self-esteem scores $(M=67.1 ; S D$ $=18.5)$ as compared to CG participants $(M=77.4 ; S D=$ $12.8 ; t=2.9, d f=48, p=.03$ ). Additionally, the authors used multivariate regression analysis to confirm the central role of psychological abuse in the relationship between depression, low self-esteem, and externalization problems. The results suggest that psychological abuse is strongly correlated to these difficulties, even when controlling for other types of maltreatment.

Three of the studies reviewed, all of which conducted with children, did not find statistically significant differences between children with and without a history of maltreatment in terms of self-esteem (Hibbard et al., 1992; Kim \& Cicchetti, 2004; Lynch \& Cicchetti, 1998). However, regression analyses indicated an association between maltreatment (sexual and physical abuse, and neglect) and self-esteem (Bolger et al., 1998; Hibbard et al., 1992; Kim \& Cicchetti, 2004; Lynch \& Cicchetti, 1998).

The severity and chronicity of exposure to maltreatment seem to affect psychological adjustment results. In a study by Bolger et al., (1998), these variables were associated with lower attached to peers and poor self-esteem.

The results also show that self-esteem plays an important mediating role during childhood. Kim and Cicchetti (2004), for instance, found that self-esteem mediates the link between the quality of the mother-child relationship and the impact of maltreatment upon social functioning. The authors found that the presence of maltreatment and insecurity in the mother-child relationship negatively influences the child's self-esteem and social competence, leading to impairment in childhood adjustment. 
Pacheco, J. T. B., Irigaray, T. Q., Werlang, B. (in memoriam), Nunes, M. L. T. \& Argimon, I. I. L. (2014). Childhood Maltreatment and Psychological Adjustment: A Systematic Review.

Studies in adults have found significant differences in self-esteem between GE and GC (Arata et al., 2005; Herrenkohl et al., 2012; Shen, 2009; Van Bruggen et al., 2006), with members of the former displaying inferior levels of self-esteem than the latter. Furthermore, individuals with a history of multi-type maltreatment presented worse self-esteem than individuals who did not suffer abuse or had a history of a single type of abuse. Herrenkohl et al. (2012), beyond the comparative analysis between the groups, performed the multivariate linear regression analysis indicated that exposure to childhood maltreatment was a significant predictor of self-esteem in adulthood ( $\beta$ $=-.19, p<.01$ ).

In contrast with other studies that investigated selfesteem in adults, Shen (2009) examined the impact of childhood exposure to both interparental violence and physical abuse upon self-esteem in adults and examined the differences between gender. Participants exposed to both types of violence in childhood reported lower selfesteem than those who did not experience maltreatment, or experienced a single type of it. The group exposed to both forms of violence reported lower scores of self-esteem than women in the same conditions. The author concludes that physical abuse can contribute to impairments in development and lead to a model of the self as incompetent and deserving of punishment.

Contrary to what was observed in studies with children and adolescents, studies with adults have found differences between the CG and EG. Donnellan, Kenny, Trzesniewski, Lucas and Conger (2012) suggest that self-esteem increased consistently as the child develops, so that making inferences about the individual's self-esteem based on a single assessment may be a methodological limitation. Furthermore, it is possible that the impact of life events upon self-esteem may be more clearly observed in adulthood, as there is greater consistency in self-esteem by this point in development (Donnellan et al., 2012).

Results regarding academic achievement, social competency and peer relationships are consistent among the analyzed studies (De Bellis et al., 2009; Eckenrode et al., 1993; Kaufman \& Cicchetti, 1989; Kim \& Cicchetti, 2010; Kinard, 1999b, 2001; Sullivan \& Knutson, 2000). Children exposed to maltreatment presented significantly poorer academic performance than non-exposed peers (De Bellis et al., 2009; Eckenrode et al., 1993; Kaufman \& Cicchetti, 1989; Kinard, 1999b, 2001; Sullivan \& Knutson, 2000). Academic performance was investigated by the authors through the analysis of academic results, disciplinary problems, school absences and number of grade repetitions. When the types of maltreatment were analyzed separately, neglect was found to be more strongly associated with negative academic performance (De Bellis et al., 2009; Eckenrode et al., 1993), while physical abuse was associated with problems related to discipline and aggressiveness (Eckenrode et al., 1993). These findings were congruent with those of other studies, who found that childhood maltreatment could lead to academic difficulties (Erickson, Egeland, \& Pianta, 1989; Kendall-Tackett \& Eckenrode, 1996; Kurtz, Gaudin, Wodarski, \& Howing, 1993; Rowe \& Eckenrode, 1999; Shonk \& Cicchetti, 2001). These changes in academic performance could be a result of greater difficulties in concentration (Carlson \& Kashani, 1988; Manly, Cicchetti, \& Barnett, 1994), decreased motivation (Carlson \& Kashani, 1988; Shonk \& Cicchetti, 2001), short-term memory impairment (Lauer et al., 1994), impulsivity and deficits in executive functioning (Manly et al., 1994).

As for peer relationships, children who suffered maltreatment displayed more elevated levels of rejection toward classmates, and lower levels of peer acceptance (Kim \& Cicchetti, 2010). The longitudinal analyses in the study by Kim and Cicchetti (2010) also revealed that maltreatment, particularly neglect, physical and sexual abuse and multi-type trauma, as well as earlier onset, are related to emotional dysregulation; this, in turn, may lead to the development of behavior problems, contributing indirectly to negative relationships with peers.

Studies of social competence also suggest impairments in this ability in children exposed to maltreatment (Kim \& Cicchetti, 2004). Kinard (1999a) investigated motherchild dyads and their perceptions of the child's social competence. Participants were divided in four groups according to exposure to maltreatment (physical abuse, sexual abuse, neglect and no exposure). No statistically significant differences were found between self-reports of perceived social competence by children in the $\mathrm{CG}$ and EG. However, the comparison among groups of mothers indicated that those whose children were exposed to maltreatment provided more negative assessments of their children's social competence.

Vondra et al. (1989) investigated social competence in children of two different age groups, comparing ones who were exposed with ones not exposed to maltreatment. In this study, the younger age group, children exposed to maltreatment obtained better social competence scores than non-victims. However, these results were not found in the group of older children. The results of these two studies could be ascribed to low accuracy in children's self-perceived social competence. A second possibility could be that, in cases of exposure to maltreatment, selfperceptions of social competence and control over the environment (Vondra et al., 1989) might have adaptive value as a compensatory/coping strategy.

In general, the studies included in this systematic review show that an exposure to childhood maltreatment may cause impairments on self-esteem, social competence, peer relationships, and academic performance. Given that, there is a consistency about the negative impact of exposure to childhood maltreatment on children and adults, it is important develop studies that explore the mechanisms which this negative effect happens. For example, Cicchetti et al. (2000) suggest that the relationship of the mother-child 
dyad can protect children from the adverse effects from exposure to maltreatment. Thus, there is a methodological challenge for future studies in this area. Identify the impact of childhood maltreatment on psychological adjustment and the mechanisms by which this impact happens, beyond develop appropriate instruments to assess the maltreatment and other psychological variables will contribute significantly to the planning of direct and indirect interventions in situations of child victimization.

\section{Final Considerations}

The results obtained in this systematic literature review underscore the negative effects of exposure to childhood maltreatment on self-esteem, social competence, peer relationships, and academic performance. Children exposed to maltreatment had a worse performance in these aspects as compared to children who were not exposed to such conditions, suggesting that the experience of maltreatment is a risk factor for psychological adjustment.

Self-esteem was the most extensively studied variable, most frequently assessed through the Rosenberg SelfEsteem Scale (Rosenberg, 1965). The results obtained corroborate the developmental perspective of self-esteem (Donnellan et al., 2012), as impairment in individuals exposed to maltreatment was most consistently identified in adults. However, even studies that did not find statistically significant differences between the EG and CG found correlations between exposure to maltreatment and self-esteem.

Social competence and relationships with peers were analyzed by a small number of studies, showing that the relationship between these variables and the experience of maltreatment requires further investigation. Unlike the other variables analyzed by the present review, peer relationships were assessed through behavioral tasks (Bolger et al., 1998; Kim \& Cicchetti, 2010), indicating a possible methodological limitation in the assessment of this variable. Furthermore, impairment in this aspect appears to be mediated by the development of behavior problems that occur as a result of exposure to maltreatment.

The analysis of articles for this systematic literature review also pointed to some important methodological limitations. These limitations include: (a) the diversity of instruments used to assess the variables analyzed by this study; (b) age distribution in samples studied is usually limited to children/adolescents, with only four studies analyzing adults; and (c) assessment of maltreatment varied among studies, ranging from self-report to case registries in social service agencies.

This systematic literature review has some methodological limitations that must be mentioned. The inclusion criteria of the articles provide greater empirical evidence, however exclude articles with other designs, such as qualitative research. Moreover, under these criteria were excluded articles published in other languages, like French, Spanish and Portuguese.
The development of systematic review involving major empirical studies enabled the description of the profile of the samples studied, the main assessment instruments used, and the effects of exposure the maltreatment on the variables of interest. These results intended to contribute to the research on the impact of exposure to maltreatment on psychological adjustment, both from the point of view of psychological practice, as the development of new researches.

\section{References}

Amazarray, M. R., \& Koller, S. H. (1998). Alguns aspectos observados no desenvolvimento de crianças vítimas de abuso sexual. Psicologia: Reflexão e Crítica, 11(3), 546-555.

Arata, C. M., Langhinrichsen-Rohling, J., Bowers, D., \& O'Farrill-Swails, L. (2005). Single versus multi-type maltreatment: An examination of the long-term effects of child abuse. Journal of Aggression, Maltreatment and Trauma. 11(4), 29-52. doi:10.1300/J146v11n04_02

Bernstein, D. P., Fink, L., Handelsman, L., Foote, J., Lovejoy, M., Wenzel, K., ...Ruggiero, J. (1994). Initial reliability and validity of a new retrospective measure of child abuse and neglect. American Journal of Psychiatry, 151(8), 1132-1136.

Bernstein, D. P., Stein, J. A., Newcomb, M. D., Walker, E., Pogge, D., Ahluvalia, T., ...Zule, W. (2003). Development and validation of a brief screening version of the childhood trauma questionnaire. Child Abuse Neglect, 27(2), 169-190. doi:10.1016/S0145-2134(02)00541-0

Bolger, K. E., Patterson, C., \& Kupersmidt, J. B. (1998). Peer relationships and self-esteem among children who have been maltreated. Child Development, 69(4), 1171-1197.

Bordin, I. A., Duarte, C. S., Peres, C. A., Nascimento, R., Curto, B. M., \& Paula, C. S. (2009). Severe physical punishment: Risk of mental health problems for poor urban children in Brazil. Bull World Health Organization, 87(5), 336-344. doi:10.2471/BLT.07.043125

Borges, J. L., \& Dell'Aglio, D. D. (2008). Relação ente abuso sexual na infância, Transtorno de Estresse Pós Traumático e prejuízos cognitivos. Psicologia em Estudo, 13(2), 371-379.

Buckle, S., Lancaster, S., Powell, M., \& Higgins, D. (2005). The relationship between child sexual abuse and academic achievement in a sample of adolescent psychiatric inpatients. Child Abuse \& Neglect, 29(9), 1031-1047. doi:10.1016/j. chiabu.2004.12.013

Carlson, G. A., \& Kashani J. H. (1988). Phenomenology of major depression from childhood through adulthood: Analysis of three studies. The American Journal of Psychiatry, 145(10), 1222-1225.

Chapple, C., Tyler, K., \& Bersani, B. (2005). Child neglect and adolescent violence: Examining the effects of self-control and peer rejection. Violence and Victims, 20(1), 39-53.

Cicchetti, D., \& Rogosch, F. A. (2002). A developmental psychopathology perspective on adolescence. Journal of Consulting and Clinical Psychology, 70(1), 6-20. doi:10.1037/0022006X.70.1.6

Cicchetti, D., Toth, S. L., \& Maughan, A. (2000). An ecologicaltransactional model of child maltreatment. In A. Sameroff, M. Lewis, \& S. Miller (Eds.), Handbook of developmental psychopathology (pp. 689-722). New York: Kluwer Academic. 
Pacheco, J. T. B., Irigaray, T. Q., Werlang, B. (in memoriam), Nunes, M. L. T. \& Argimon, I. I. L. (2014). Childhood Maltreatment and Psychological Adjustment: A Systematic Review.

Cicchetti, D., \& Valentino, K. (2006). An ecological transactional perspective on child maltreatment: Failure of the average expectable environment and its influence upon child development. In D. Cicchetti \& D. J. Cohen (Eds.), Developmental psychopathology: Risk, disorder, and adaptation (pp. 129201). New York: Wiley.

Coopersmith, S. C. (1981). Self-esteem Inventory. Palo Alto, CA: Consulting Psychologists Press.

De Bellis, M. D., Hooper, S. R., Spratt, E. G., \& Woolley, D. P. (2009). Neuropsychological findings in childhood neglect and their relationships to pediatric PTSD. Journal of the International Neuropsychological Society, 15(6), 868-878. doi:10.1017/S1355617709990464

Dodge, K. A., Pettit, G. S., \& Bates, J. E. (1994). Socialization mediators of the relation between socio-economic status and child conduct problems. Child Development, 65(2), 649-665.

Donnellan, M. B., Kenny, D. A., Trzesniewski, K. H., Lucas, R. E., \& Conger, R. D. (2012). Using trait-state models to evaluate the longitudinal consistency of global self-esteem from adolescence to adulthood. Journal of Research in Personality, 46(6), 634-645. doi:10.1016/j.jrp.2012.07.005

Drezett, J., Caballero, M., Juliano, Y., Prieto, E. T., Marques, J. A., \& Fernandes, C. E. (2001). Estudo de mecanismos e fatores relacionados com o abuso sexual em crianças e adolescentes do sexo feminino. Jornal de Pediatria, 77(5), 413-419.

Eckenrode, J., Laird, M., \& Doris, J. (1993). School performance and disciplinary problems among abused and neglected children. Developmental Psychology, 29(1), 53-62.

Erickson, M., Egeland, B., \& Pianta, R. (1989). The effects of maltreatment on the development of young children. In D. Cicchetti \& V. Carlson (Eds.), Child maltreatment: Theory and research on the causes and consequences of child abuse \& neglect (pp. 647-684). New York: Cambridge University Press.

Habigzang, L. F., Stroeher, F. H., Hatzenberger, R., Cunha, R. C., Ramos, M. S., \& Koller, S. H. (2009). Grupoterapia cognitivo-comportamental para crianças e adolescentes vítimas de abuso sexual. Revista de Saúde Pública, 43(1) 70-78

Harter, S. (1985). Manual for the self-perception profile for children. Denver, CO: University of Denver.

Herrenkohl, T. I., Klika, J., Herrenkohl, R. C., Russo, M. G., \& Dee, T. (2012). A prospective investigation of the relationship between child maltreatment and indicators of adult psychological well-being. Violence Victims, 27(5), 764-776.

Hibbard, R. A., Spence, C., Tzeng, O. C., Zollinger, T., \& Orr, D. P. (1992). Child abuse and mental health among adolescents in dependent care. Journal of Adolescent Health, 13(2), 121-127.

Kaufman, J., \& Cicchetti, D. (1989). Effects of maltreatment on school-age children's socioemotional development: Assessments in a day-camp setting. Developmental Psychology, 25(4), 516-524.

Kendall-Tackett, K. A., \& Eckenrode, J. (1996). The effects of neglect on academic achievement and disciplinary problems: A developmental perspective. Child Abuse \& Neglect, 20(3), 161-169. doi:10.1016/S0145-2134(95)00139-5

Kendall-Tackett, K. A., Williams, L. M., \& Finkelhor, D. (1993). Impact of sexual abuse on children: A review and synthesis of recent empirical studies. Psychological Bulletin, 113(1), 164-180. doi:10.1037/0033-2909.113.1.164

Kim, J., \& Cicchetti, D. (2004). A longitudinal study of child maltreatment, mother-child relationship quality and maladjustment: The role of self-esteem and social competence. Journal of Abnormal Child Psychology, 32(4), 341-354.
Kim, J., \& Cicchetti, D. (2010). Longitudinal pathways linking child maltreatment, emotion regulation, peer relations, and psychopathology. Journal of Child Psychology Psychiatry, 51(6), 706-716. doi:10.1111/j.1469-7610.2009.02202.x

Kinard, E. M. (1999a). Perceived social skills and social competence in maltreat children. American Journal of Orthopsychiatry, 69(4), 465-468.

Kinard, E. M. (1999b). Psychosocial resources and academic performance in abused children. Children and Youth Services Review, 21(5), 351-376. doi:10.1016/S0190-7409(99)00026-2

Kinard, E. M. (2001). Perceived and actual academic competence in maltreated children. Child Abuse \& Neglect, 25(1), 33-45. doi:10.1016/S0145-2134(00)00219-2

Kurtz, P. D., Gaudin, J. M., Wodarski, J. S., \& Howing P. T. (1993). Maltreatment and the school-aged child: School performance consequences. Child Abuse \& Neglect, 17(5), 581-589.

Lauer, R. E., Giordani, B., Boivin, M. J., Halle, N., Glasgow, B., Alessi, N. E., \& Berent, S. (1994). Effects of depression on memory performance and metamemory in children. Journal of the American Academy of Child and Adolescent Psychiatry, 33(5), 679-685. doi:10.1097/00004583-199406000-00009

Leeson, F. J., \& Nixon, R. D. V. (2011). The role of children's appraisals on adjustment following psychological maltreatment: A pilot study. Journal of Abnormal Child Psychology, 31(5), 759-771. doi:10.1007/s10802-011-9507-5

Levendosky, A. A., Okun, A., \& Parker, J. G. (1995). Depression and maltreatment as predictors of social competence and social problem-solving skills in school-age children. Child Abuse Neglect, 19(10), 1183-1195. doi:10.1016/01452134(95)00086-N

Lynch, M., \& Cicchetti, D. (1998). An ecological-transactional analysis of children and contexts: The longitudinal interplay among child maltreatment, community violence, and children's symptomatology. Development and Psychopathology, 10(2), 235-257. doi:10.1017/S095457949800159X

Manly, J. T., Cicchetti, D., \& Barnett, D. (1994). The impact of subtype, frequency, chronicity, and severity of child maltreatment on social competence and behavior problems. Development and Psychopathology, 6(1), 121-143.

Masten, A. S., \& Coatsworth, J. D. (1998). The development of competence in favorable and unfavorable environments: Lessons from research on successful children. American Psychologist, 53(2), 205-220.

Mulrow, C. D., \& Oxman, A. (1997). How to conduct a Cochrane systematic review. San Antonio, TX: Cochrane Collaboration.

Pears, K. C., Kim, H. K., \& Fisher, P. A. (2008). Psychosocial and cognitive functioning of children with specific profiles of maltreatment. Child Abuse \& Neglect, 32(10), 958-971. doi:10.1016/j.chiabu.2007.12.009

Proctor, L. J., Skriner, L. C., Roesch, S., \& Litrownik, A. J. (2010). Trajectories of behavioral adjustment following early placement in foster care: Predicting stability and change over eight years. Journal American Academic Child Adolescent Psychiatry, 49(5), 464-473.

Rogosch, F., Oshri, A., \& Cicchetti, D. (2010). From child maltreatment to adolescent cannabis abuse and dependence: A developmental cascade model. Development and Psychopathology, 22(4), 883-897. doi:10.1017/S0954579410000520

Rosenberg, M. (1965). Society and the adolescent self image. Princeton, NJ: Princeton University Press.

Rowe, E., \& Eckenrode, J. (1999). The timing of academic difficulties among maltreated and nonmaltreated children. Child Abuse \& Neglect, 23(8), 813-832. doi:10.1016/S01452134(99)00044-7 
Shen, C. T. (2009). Self-esteem of young adults experiencing interparental violence and child physical maltreatment parental and peer relationships as mediators. Journal of Interpersonal Violence, 24(5), 770-794. doi:10.1177/0886260508317188

Shonk, S. M., \& Cicchetti, D. (2001). Maltreatment, competency deficits, and risk for academic and behavioral maladjustment. Developmental Psychology, 37(1), 3-14.

Soler, L., Paretilla, C., Kirchner, T., \& Forns, M. (2012). Effects of poly-victimization on self-esteem and post-traumatic stress symptoms in Spanish adolescents. European Child Adolescent Psychiatry, 21(11), 645-653. doi:10.1007/s00787-012-0301-x

Sullivan, P. M., \& Knutson, J. F. (2000). The prevalence of disabilities and maltreatment among runaway children. Child Abuse \& Neglect, 24(10), 1275-1288. doi:10.1016/S01452134(00)00181-2

Van Bruggen, L., Runtz, M., \& Kadlec, H. (2006). Sexual revictimization: The role of sexual self-esteem and dysfunctional sexual behaviors. Child Maltreatment, 11(2), 131-145. doi:10.1177/1077559505285780

Vitolo, Y. L., Fleitlich-Bilyk, B., Goodman, R., \& Bordin, I. A (2005). Parental beliefs and child-rearing attitudes and mental health problems among schoolchildren. Revista de Saúde Pública, 39(5), 716-724.

Vondra, J., Barnett, D., \& Cicchetti, D. (1989). Perceived and actual competence among maltreated and comparison school children. Development and Psychopathology, 1(3), 237-255. 